\title{
Multikulturalisme dan Dialog dalam Pendidikan Agama Katolik
}

\author{
Hubertus Aditya Prabowo a,1 \\ Program Magister Filsafat Keilahian, Fakultas Teologi Universitas Sanata Dharma, Yogyakarta, Indonesia a \\ hubertusaditya@gmail.com ${ }^{1}$
}

\section{KEYWORDS :}

Multikulturalisme,

Pendidikan,

Katolik,

Dialog,

Kesamaan.

\begin{abstract}
Religious education has two dimensions of teaching, namely vertical dimension and horizontal dimension. Paying attention to the horizontal dimension is a form of teaching that human must live in love, as God loves human. According to the author, conflicts, wars and murders in the name of God are forms of failure in understanding religious teachings. One of various ways is used to counteract a tendency of religious radicalism that occurs, one of which is by applying the values of multiculturalism that respect all human differences and by implementing dialogue so that humans continue to communicate with each other and make a collective agreement to live side by side in peace. According to Theodora van Bowen, religious education has a role in realizing the values of multiculturalism and dialogue. The research in this article uses the quantitative method to see how much multiculturalism values have been applied in the learning material in the book of "Pendidikan Agama Katolik dan Budi Pekerti untuk kelas V dan VI SD". The book contains the values of multiculturalism, including: a) an appreciation of the reality of cultural plurality in society; b). recognition of human dignity and rights; c) development of responsibility towards society. These values are expected to help students live in an atmosphere of brotherhood and dialogue within religious, ethnic and cultural differences.
\end{abstract}

\section{LATAR BELAKANG}

Bangsa Indonesia saat ini sedang mengalami berbagai tantangan kehidupan bersama yang kompleks, khususnya terkait dengan berkembangnya paham radikalisme yang mengatasnamakan agama. Paham radikalisme agama dapat mengganggu pola kehidupan bermasyarakat di Indonesia yang majemuk. Beberapa ciri dari tindakan yang dianggap radikal adalah, pertama sikap intoleran, sikap yang tidak mau menghargai keyakinan orang lain. Kedua sikap fanatik, sikap yang selalu merasa diri paling benar 
dan menganggap orang lain selalu salah. Ketiga sikap eksklusif, yakni sikap yang cenderung menolak adanya perbedaan dan keempat sikap revolusioner yakni sikap yang cenderung menggunakan kekerasan untuk mencapai tujuannya. ${ }^{1}$

Menurut hasil penelitian yang dilakukan oleh Badan Inteligen Negara (BIN) terhadap tiga perguruan tinggi di Indonesia (tidak diungkapkan identitas perguruan tinggi tersebut), paham radikalis ini mengalami perkembangan yang cukup signifikan di tengah dunia pendidikan. Menurut survei yang dilakukan, sebanyak 39\% peserta didik terpapar paham radikal. Penelitian yang sama juga mengungkapkan bahwa sebanyak 24\% peserta didik dan 23\% pelajar SMA mengatakan bahwa mereka sangat mendukung jihad demi tegaknya negara Islam. $^{2}$

Penelitian tersebut menunjukkan sebuah fakta yang sangat mengejutkan bahwa sekolah yang diharapkan menjadi tempat pembinaan peserta didik untuk menjadi lebih baik, justru menjadi lahan subur bagi berkembangnya paham radikalisme yang merusak kehidupan bersama. Maka, penulis menyarankan bahwa pendidikan di sekolah perlu untuk menerapkan suatu pendidikan yang menanamkan dengan sungguhsungguh nilai-nilai multikulturalisme yang lebih ramah dan mendukung kehidupan bersama.

Penanaman nilai-nilai multikulturalisme juga sangat penting diterapkan dalam pendidikan agama di sekolah. Hal ini

\footnotetext{
A.M. Hendroprioyono, Terorisme: Fundamentalis Kristen, Yahudi dan Islam (Jakarta: Buku Kompas, 2009), 13.

Wisnugroho Akbar, "BIN Ungkap 39 Persen Mahasiswa Terpapar Radikalisme" (29 April 2018), tersedia dari https://www. cnnindonesia.com/nasional/20180429023027-20-294442/ bin-ungkap-39-persen-mahapeserta didik-terpaparradikalisme; diakses pada 28 Juli 2020.
}

dilakukan untuk menanamkan sikap penghargaan akan yang lain terutama mereka yang berbeda keyakinan. Perbedaan keyakinan bukan sebagai alasan untuk saling membenci, tetapi menjadikan yang lain sebagai saudara dan bersama-sama menimba hal-hal baik bagi kehidupan bersama. Terkait hal ini, langkah yang dapat diambil ialah dengan memperhatikan bahan-bahan pelajaran agama dalam buku pelajaran agama yang diajarkan di sekolah. Sangat baik jika materi-materi pengajaran juga terarah pada nilai-nilai multikulturalisme. Hal ini juga merupakan upaya untuk mencegah paham radikalisme yang salah terhadap pemahaman agama tertentu yang dapat merusak kehidupan bersama.

Penilaian terhadap buku-buku pelajaran agama dapat dilihat dari isinya, apakah mendukung paham-paham radikalisme atau memuat nilai-nilai multikulturalisme. Nilainilai multikulturalisme yang ditanamkan diharapkan dapat mencegah bibit-bibit radikalisme. Nilai-nilai multikulturalisme memuat pengajaran tentang penghargaan dan penghormatan terhadap orang lain, bukan hanya yang berbeda suku dan budaya, tetapi juga yang berbeda agama. Apakah buku pelajaran Pendidikan Agama Katolik dan Budi Pekerti untuk kelas V dan VI $\mathrm{SD}^{3}$ terbitan Kementerian Pendidikan dan Kebudayaan edisi revisi tahun 2017 mengandung nilai-nilai multikulturalisme? Nilai-nilai multikulturalisme seperti apa yang terkandung dalam buku pelajaran tersebut?

Mengapa meneliti buku pelajaran Pendidikan Agama Katolik dan Budi

\footnotetext{
Buku dengan judul "Pendidikan Agama Katolik dan Budi Pekerti untuk Kelas V SD" dan "Pendidikan Agama Katolik dan Budi Pekerti untuk Kelas VI SD" ini disusun oleh FX. Dapiyanta dan Marianus Didi Kasmudi, dan diterbitkan oleh Kementerian Pendidikan dan Kebudayaan, direvisi pada tahun 2017.
} 
Pekerti? Dari pembahasan yang ada telah ditunjukkan adanya kasus radikalisme yang terjadi di dalam dunia pendidikan. Maka dari itu, perhatian terhadap pendidikan, terutama pendidikan agama menjadi sangat perlu untuk ditingkatkan. Sebagai bentuk perhatian terhadap pendidikan agama, maka kualitas dari materi-materi pelajaran agama yang diberikan harus dijaga. Dalam artikel ini, penulis melakukan penelitian terhadap kualitas materi-materi dalam buku pelajaran Pendidikan Agama Katolik dan Budi Pekerti ini dengan menggunakan perspektif multikulturalisme.

Mengapa Katolik? Memang kasus yang telah dipaparkan adalah kasus radikalisme dalam Islam. Beberapa penelitian sudah dilakukan terhadap materi-materi dalam pelajaran Pendidikan Agama Islam dan telah ditemukan bahwa nilai toleransi dapat melawan radikalisme. Hal ini telah dibuat oleh Muhammad Furqan dari program magister Pendidikan Agama Islam Universitas Negeri Maulana Malik Ibrahim, Malang pada tahun 2019. Dia membuat tesis penelitian dengan judul "Analisis NilaiNilai Toleransi dalam Teks Mata Pelajaran Pendidikan Agama Islam dan Budi Pekerti Tingkat SMA Terbitan Kemendikbud Tahun 2017”. Berangkat dari hal inilah, penulis kemudian meneliti dari sudut pandang Pendidikan Agama Katolik, seberapa besar potensi nilai-nilai multikulturalisme untuk melawan radikalisme telah diajarkan dalam materi-materi buku Pendidikan Agama Katolik dan Budi Pekerti.

\section{TINJAUAN TEORI}

\section{Multikulturalisme}

Seiring dengan kemajuan teknologi, manusia dapat semakin mudah melihat dan mengenal budaya-budaya lain dari seluruh dunia. Multikulturalisme bukanlah sematamata pengenalan terhadap berbagai jenis budaya lain, tetapi juga menjadi tuntutan bagi komunitas atau kelompok yang memiliki budaya tersebut. ${ }^{4}$ Multikulturalisme tidak hanya tentang budaya atau etnis saja, melainkan mencakup pula bidang sosial, politik, agama dan juga ekonomi. Kesadaran ini tentu tidak muncul secara tiba-tiba, tetapi selalu berkaitan dengan peristiwaperistiwa global yang terjadi seperti peristiwa kemerdekaan suatu bangsa, migrasi besarbesaran karena konflik, melemahnya suatu bangsa atau kelompok karena aksi-aksi teror.

Multikulturalisme $^{5}$ adalah aliran yang berpandangan bahwa terdapat variasi budaya di dalam kehidupan masyarakat. Tetapi lantas budaya-budaya itu saling berhubungan dan terjadi adanya kesetaraan budaya, sehingga satu entitas budaya dengan budaya lainnya tidaklah berada di dalam suasana bertanding untuk memenangkan sebuah pertarungan. ${ }^{6}$ Adapun nilai-nilai multikulturalisme dapat dikategorikan dalam enam nilai berikut ini: 1) adanya apresiasi terhadap kenyataan pluralitas budaya di dalam masyarakat; 2) pengakuan terhadap harkat dan hak asasi manusia; 3) mengembangkan sikap tanggung jawab terhadap masyarakat; 4) mengembangkan sikap tanggung jawab terhadap kehidupan bumi $;^{7}$ 5) membentuk manusia budaya dan

\footnotetext{
H.A.R. Tilaar, Multikulturalisme: Tantangan-tantangan Global Masa Depan dalam Transformasi Pendidikan Nasional (Jakarta: Grasindo, 2004), 73.

Menurut Bikhu Parekh multikulturalisme adalah sebuah masyarakat yang di dalamnya terdapat beberapa kelompok budaya yang tentunya memiliki perbedaan sistem makna, nilai, sistem sosialnya, sejarah, tradisi dan kebiasaan. Parekh, Rethinking Multikulturalism: Keberagaman Budaya dan Teori Politik, diterjemahkan dari Rethinking Multiculturalism, Cultural Diversity and Political Theory, oleh Bambang Kukuh Adi (Yogyakarta: Kanisius, 2008), 5.

6 Nur Syam, Tantangan Multikulturalisme Indonesia: Dari Radikalisme Menuju Kebangsaan (Yogyakarta: Kanisius, 2009), 79.

$7 \quad$ Muslim, "Nilai-Nilai Pendidikan Multikultural dalam Buku Teks
} 
masyarakat budaya; dan 6) mengajarkan nilai-nilai tentang kemanusiaan, kebangsaan dan kelompok etnis. ${ }^{8}$

Pendidikan multikulturalisme mengajak peserta didik untuk berpikir dan menghadapi realita sosial yang nyata dalam hidup. ${ }^{9}$ Pendidikan yang dilandasi oleh multikulturalisme atau disingkat pendidikan multikultural, merupakan desain pendidikan yang bermaksud untuk mendukung dan memperluas konsep budaya, keragaman, kesetaraan, dan demokrasi di dalam konteks sekolah, untuk menyiapkan warga yang dapat hidup bersama (to live together) dalam harmoni di tengah-tengah perbedaan. ${ }^{10}$

\section{Dialog}

Dalam dokumen Dialogue and Proclamation art. 9 dikatakan bahwa dialog menunjuk pada berbagai hubungan yang bersifat positif dan konstruktif dengan pribadi-pribadi dan jemaah dari agama lain, dalam semangat mau saling memahami dan memperkaya satu sama lain. Dialog yang dilakukan dengan agama lain merupakan salah satu bentuk dari pewartaan kabar sukacita Injil kepada setiap orang. Dialog tentu saja merupakan suatu perkembangan yang amat positif dalam pemahaman Gereja tentang hubungannya dengan agama lain. ${ }^{11}$ Nostra Aetate telah membuka kemungkinan itu. Dialog sendiri merupakan tugas khusus dari karya pewartaan dalam misi Gereja.

Bahasa Indonesia untuk Peserta Didik SMP," Riksa Bahasa 2 (2016): 5.

8 Choirul Mahfud, Pendidikan Multikultural (Yogyakarta: Pustaka Pelajar, 2006), 187.

$9 \quad$ Robert Jackson, "Inclusive Study of Religions and World Views in Schools," Social Inclusion 4 (2016): 17.

10 Syamsul Arifin, "Multikulturalisme dalam Skema Deradikalisasi Paham dan Gerakan Keagamaan Radikal di Indonesia," dalam Proceeding AICIS XIV: Buku 2, ed. Muhammad Zain dkk (Samarinda: STAIN Samarinda, 2014), 186-187.

11 Kuruvachira Jose, "Interreligious Dialogue in Dialogue and Mission," tesedia dari https://www.euclid.int/papers/JOSE\%20 KURU\%20---\%20INTERRELIGIOUS\%20DIALOGUE\%20IN\%20 DIALOGUE\%20AND\%20MISSION.pdf; diakses pada 21 Juli 2020.
Konsili Vatikan II mendorong adanya dialog dengan agama-agama lain, tetapi memang belum menyatakannya sebagai bagian dari misi penginjilan Gereja. "Wartakanlah Yesus Kristus kepada mereka yang tidak mengenal Dia dan jadikanlah mereka murid-Nya". Inilah misi Gereja yang terangkum dalam Konsili Vatikan II (LG 17; AG 6).

Dialog yang dilakukan Gereja merupakan bentuk kesaksian iman kristiani. Dalam dialog, kesaksian hidup sebagai orang Kristen merupakan salah satu unsur pokoknya. Gereja diminta untuk selalu menghargai dan bersikap sabar terhadap orang-orang dari agama lain dan budaya lain yang hidup berdampingan dengan mereka. ${ }^{12}$ Dialog berarti selalu memberikan kesaksian hidup sebagai seorang Kristen, walau tidak secara langsung melakukan evangelisasi. Kristus menjadi ukuran bagi dialog ini.

Dialog terjadi melalui pengalamanpengalaman perjumpaan dengan orang lain. Tetapi pengalaman itu tidak akan memberi pengaruh sedikit pun dalam kehidupan seseorang/kelompok, jika sikap-sikap intoleran, saling curiga, dan membenci masih bercokol dalam dirinya. Sikap curiga dan menutup diri hanya akan menimbulkan pandangan buruk terhadap orang lain. Kurangnya pengertian dan pemahaman tentang kelompok lain ini menjadikan dialog bukan sebagai sarana saling memahami, tetapi sebagai tempat untuk membela dan membenarkan diri. ${ }^{13}$

\section{METODE PENELITIAN}

Penelitian terhadap buku-buku Pendidikan Agama Katolik dan Budi Pekerti

\footnotetext{
12 Kuruvachira Jose, "Interreligious Dialogue in Dialogue and Mission", 14.

13 Jonathan Yun-Ka Tan, "A New Way of Being Church in Asia," Missiology an International Review 33 (2005): 75.
} 
ini menggunakan metode kuantitatif. ${ }^{14}$ Pengumpulan data dilakukan dengan teknik eksplorasi teks, komparasi teks, mencari teks yang sepadan. Penelitian ini bertujuan untuk memahami isi dari materi-materi pembelajaran Pendidikan Agama Katolik di sekolah dasar dan menganalisanya dalam perspektif multikulturalisme dan dialog. Hal ini diharapkan dapat mendukung pengembangan sikap dialog dalam kehidupan nyata di sekolah dasar. Selain itu hal ini dapat membantu Gereja untuk mengembangkan teologi dialog.

\section{HASIL PENELITIAN}

Nilai-nilai multikulturalisme mencakup beberapa unsur yakni: 1) adanya apresiasi terhadap kenyataan pluralitas budaya di dalam masyarakat; 2) pengakuan terhadap harkat dan hak asasi manusia; 3) mengembangkan sikap tanggung jawab terhadap masyarakat; 4) mengembangkan sikap tanggung jawab terhadap kehidupan bumi; 5) membentuk manusia budaya dan masyarakat budaya; 6) mengajarkan nilainilai tentang kemanusiaan, kebangsaan dan kelompok etnis.

Tabel berikut ini menunjukkan seberapa banyak nilai-nilai multikulturalisme yang ditemukan dalam buku pelajaran Pendidikan Agama Katolik dan Budi Pekerti untuk kelas V dan VI SD.

\section{Buku Kelas V}

\begin{tabular}{|l|c|c|c|c|}
\hline \multicolumn{1}{|c|}{ Nilai Multikulturalisme } & $\begin{array}{c}\text { Kompetensi } \\
\text { Dasar }\end{array}$ & $\begin{array}{c}\text { Bab } \\
\text { Pembahasan }\end{array}$ & $\begin{array}{c}\text { Teks } \\
\text { Materi }\end{array}$ & Total \\
\hline $\begin{array}{l}\text { Adanya apresiasi terhadap kenyataan } \\
\text { pluralitas budaya di dalam masyarakat }\end{array}$ & 4 & 1 & 7 & 12 \\
\hline $\begin{array}{l}\text { Pengakuan terhadap harkat dan hak } \\
\text { asasi manusia }\end{array}$ & 11 & 2 & 8 & 21 \\
\hline $\begin{array}{l}\text { Mengembangkan sikap tanggung jawab } \\
\text { terhadap masyarakat }\end{array}$ & 4 & 1 & 5 & 10 \\
\hline $\begin{array}{l}\text { Mengembangkan sikap tanggung jawab } \\
\text { terhadap kehidupan bumi }\end{array}$ & 1 & 2 & 3 & 4 \\
\hline $\begin{array}{l}\text { Membentuk manusia budaya dan } \\
\text { masyarakat budaya }\end{array}$ & 1 & 1 & 5 & 9 \\
\hline $\begin{array}{l}\text { Mengajarkan nilai-nilai tentang } \\
\text { kemanusiaan, kebangsaan dan } \\
\text { kelompok etnis }\end{array}$ & 3 & & & 3 \\
\hline
\end{tabular}

\footnotetext{
$14 \quad$ Mohammad Mulyadi, "Penelitian Kuantitatif dan Kualitatif serta Pemikiran Dasar Menggabungkannya," Jurnal Studi Komunikasi dan Media 15 (2011): 131.
} 


\section{Buku Kelas VI}

\begin{tabular}{|l|c|c|c|c|}
\hline \multicolumn{1}{|c|}{ Nilai Multikulturalisme } & $\begin{array}{c}\text { Kompetensi } \\
\text { Dasar }\end{array}$ & $\begin{array}{c}\text { Bab } \\
\text { Pembahasan }\end{array}$ & $\begin{array}{c}\text { Teks } \\
\text { Materi }\end{array}$ & Total \\
\hline $\begin{array}{l}\text { Adanya apresiasi terhadap kenyataan } \\
\text { pluralitas budaya di dalam masyarakat }\end{array}$ & 7 & 2 & 8 & 17 \\
\hline $\begin{array}{l}\text { Pengakuan terhadap harkat dan hak } \\
\text { asasi manusia }\end{array}$ & 12 & 2 & 8 & 22 \\
\hline $\begin{array}{l}\text { Mengembangkan sikap tanggung jawab } \\
\text { terhadap masyarakat }\end{array}$ & 1 & 1 & 2 & 9 \\
\hline $\begin{array}{l}\text { Mengembangkan sikap tanggung jawab } \\
\text { terhadap kehidupan bumi }\end{array}$ & 6 & 1 & 3 & 7 \\
\hline $\begin{array}{l}\text { Membentuk manusia budaya dan } \\
\text { masyarakat budaya }\end{array}$ & 3 & 1 & & 5 \\
\hline $\begin{array}{l}\text { Mengajarkan nilai-nilai tentang } \\
\text { kemanusiaan, kebangsaan dan } \\
\text { kelompok etnis }\end{array}$ & & 1 & & \\
\hline
\end{tabular}

Jika semua data ditotal, maka akan ditemukan data berikut ini:

\begin{tabular}{|l|c|}
\hline \multicolumn{1}{|c|}{ Nilai Multikulturalisme } & Total \\
\hline $\begin{array}{l}\text { Adanya apresiasi terhadap kenyataan pluralitas budaya di dalam } \\
\text { masyarakat }\end{array}$ & 29 \\
\hline Pengakuan terhadap harkat dan hak asasi manusia & 26 \\
\hline Mengembangkan sikap tanggung jawab terhadap masyarakat & 32 \\
\hline Mengembangkan sikap tanggung jawab terhadap kehidupan bumi & 4 \\
\hline Membentuk manusia budaya dan masyarakat budaya & 13 \\
\hline $\begin{array}{l}\text { Mengajarkan nilai-nilai tentang kemanusiaan, kebangsaan dan kelompok } \\
\text { etnis }\end{array}$ & 16 \\
\hline
\end{tabular}

Dapat dilihat bahwa hasil penelitian menemukan tiga nilai multikulturalisme penting yaitu: a) adanya apresiasi terhadap kenyataan pluralitas budaya di dalam masyarakat; b).pengakuan terhadap harkat dan hak asasi manusia; c) mengembangkan sikap tanggung jawab terhadap masyarakat. Dapat dilihat juga dari hasil penelitian tersebut bahwa nilai-nilai multikulturalisme telah ditanamkan dalam buku pelajaran bagi para peserta didik dengan menekankan aspek pluralitas, persamaan dan juga 
dampak bagi masyarakat di sekitar. Ketiga aspek ini dapat dirangkum dengan kata kesetaraan. Mengapa kesetaraan? Karena di dalam kesetaraan ada unsur penghargaan terhadap keunikan masing-masing individu ataupun kelompok, dan penghargaan terhadap martabat manusia.

Apresiasi terhadap pluralitas di dalam masyarakat menjadi pembuka bagi tumbuhnya multikulturalisme. Penghargaan akan adanya perbedaan, membawa peserta didik untuk menyadari bahwa banyaknya budaya akan memperkaya diri mereka sendiri. Kemudian, sikap ini akan membawa peserta didik memandang perbedaan, atau pluralitas yang ada sebagai elemen-elemen di dalam masyarakat yang mempunyai kedudukan sama dalam memberikan dampak positif bagi masyarakat. Maka, diharapkan tidak ada lagi diskriminasi terhadap suku atau agama tertentu karena semua manusia darimana pun ia berasal, mempunyai martabat yang sama. Setelah kedua unsur di atas dapat diwujudkan di dalam masyarakat, maka dampak selanjutnya yang diharapkan adalah dapat hidup berdampingan dengan damai dan tenteram di dalam masyarakat.

\section{PEMBAHASAN}

\section{Pendidikan Multikulturalisme}

Hasil penelitian menemukan tiga nilai multikulturalisme penting yaitu: a) adanya apresiasi terhadap kenyataan pluralitas budaya di dalam masyarakat; b) pengakuan terhadap harkat dan hak asasi manusia; c) mengembangkan sikap tanggung jawab terhadap masyarakat. Maka, dapat dikatakan bahwa materi-materi pelajaran yang ada di buku tersebut tidak hanya mengarahkan para peserta didik untuk semakin mendalami iman Katolik, melainkan semakin pula memahami bahwa mereka hidup di tengah pluralitas agama dan budaya. Situasi ini ditanamkan terlebih dahulu dalam materimateri pelajaran yang ada dan barulah setelah para peserta didik menyadari pluralisme yang ada, mereka diajak untuk saling menghormati hak asasi manusia dan turut serta dalam pengembangannya di masyarakat.

Di Indonesia, pendidikan agama merupakan pilar yang sangat penting dalam dunia pendidikan, baik formal maupun non formal, ${ }^{15}$ dengan alasan bahwa pendidikan agama dapat meningkatkan rasa saling mengerti dan toleransi beragama. Dalam pendidikan formal, pendidikan agama diatur oleh kurikulum yang berlaku. Pada penelitian yang dilakukan terhadap buku Pendidikan Agama Katolik dan Budi Pekerti, kurikulum pendidikan yang dipakai adalah Kurikulum 2013. Dalam model pendidikan resmi di sekolah, pendidikan agama diberikan sesuai dengan agama yang dianut oleh masingmasing peserta didiknya.

Materi-materi pengajaran yang disediakan juga telah mengarah pada praktik dialog sehari-hari. Misalnya dalam materi tentang "Aku Warga Dunia” yang terdapat pada halaman 12-20 dijabarkan demikian:

Tuhan menghendaki agar manusia mengolah dan menghuni bumi ini dengan lestari dan damai. Gereja pun mengajak umat kristiani untuk terlibat dalam kehidupan bersama masyarakat dunia. Kegembiraan dan duka masyarakat zaman ini, menjadi kegembiraan dan duka seluruh umat kristiani. Itulah panggilan Tuhan bagi seluruh umat manusia untuk

\footnotetext{
5 Theodora van Bowen, Religious Education for Tolerance: An Exploratory Study of the Policies and Practices of Religious Education in Public, Christian and Islamic Secondary Schools in the Netherlands and Indonesia (Nijmegen: Radboud Universiteit Nijmegen, 2017), 35.
} 
hidup bersama dan membangun bumi yang lestari serta damai. ${ }^{16}$

Di dalam materi "Terlibat dalam Pelestarian Lingkungan” yang terdapat dalam halaman 101-106, juga dijelaskan tentang penurunan kualitas alam karena banyak hal:

Sebab mendasar dari semua itu ialah sikap manusia terhadap lingkungan yang hanya melihat sebagai objek pemenuhan hidupnya. Seperti St. Fransiskus Asisi kita diharapkan memperlakukan alam sebagai saudara. Dengan itu, kita tidak akan semena-mena bertindak atasnya. Sebagaimana dikemukakan dalam Mazmur 104:10-18, 24, 31 bahwa memang alam diciptakan demi manusia, namun Tuhan memandang semuanya baik. Maka manusia harus mempertahankan alam agar tetap baik sebagaimana Allah memandangnya. Sehubungan dengan itu kegiatan pelestarian lingkungan mendesak untuk dilakukan. ${ }^{17}$

Dalam proses pendidikan agama, memang perlu untuk diperhatikan terkait hubungan kita dengan saudara-saudari kita yang berbeda agama, suku dan budaya. Hubungan dengan sesama akan semakin terjalin dengan adanya berbagai macam kegiatan bersama seperti: belajar bersama, kerja bakti, bermain bersama, dan kerja kelompok. Kegiatan bersama tersebut adalah bentuk dari dialog yang nyata dalam pendidikan agama Katolik yang coba diterapkan. Dengan demikian, diharapkan peserta didik mampu menjadikan mereka yang berbeda sebagai sesamanya.

Selain itu, para guru agama juga berperan dalam meningkatkan kualitas hidup para

\footnotetext{
16 FX. Dapiyanta dan Marianus Didi Kasmudi, Pendidikan Agama Katolik dan Budi Pekerti Kelas VI Jakarta: Kementerian Pendidikan dan Kebudayaan, 2017), 12.

17 FX. Dapiyanta dan Marianus Didi Kasmudi, Pendidikan Agama Katolik dan Budi Pekerti Kelas V, 101.
}

peserta didik berdasarkan nilai-nilai agama, untuk memperoleh pengetahuan umum tentang kemanusiaan dan bagaimana memperlakukan orang lain secara sama dan penuh respek. ${ }^{18} \mathrm{Jika}$ manusia diciptakan oleh Tuhan, maka kita semua adalah sama. Para peserta didik diharapkan tidak hanya cakap dalam pelajaran-pelajaran formal di sekolah, melainkan mampu menerapkan nilai-nilai keberagaman untuk memahami dan menghargai keberadaan manusia lainnya yang berbeda agama maupun latar belakang lainnya. ${ }^{19}$

\section{Persamaan untuk Memahami Multikulturalisme}

Manusia tidak berhak untuk menguasai (menjadikannya barang milik) manusia lainnya karena manusia telah menerima anugerah martabat dari Allah pencipta mereka. Setiap orang berhak untuk melindungi kepemilikan mereka yang paling mendasar yakni martabat yang ada dalam diri mereka. ${ }^{20}$ Martabat menjadi kepunyaan manusia yang paling mendasar. Sejak zaman Ambrosius, para teolog Gereja memandang martabat manusia dalam kacamata gambar Allah/ imago Dei. ${ }^{21}$ Dengan mempunyai martabat, manusia berhak untuk dihormati dan diperhatikan karena mereka memiliki hubungan khusus dengan Allah pencipta. Semua manusia mempunyai kesetaraan martabat di hadapan Allah.

Bagian bab pertama dari buku Pendidikan Agama Katolik dan Budi Pekerti (halaman 1-22) untuk kelas V SD membahas tentang laki-laki dan perempuan sebagai citra Allah.

\footnotetext{
18 Theodora van Bowen, Religious Education for Tolerance, 28.

19 Ainul Yaqin, Pendididkan Multikultural: Cross-Cultural Understanding untuk Demokrasi dan Keadilan (Yogyakarta: Nuansa Aksara, 2005), 35.

20 N.Vorster, "A Theological Perspective on Human Dignity, Equality and Freedom," Verbum et Ecclesia 33 (2012): 2.

21 N.Vorster, "A Theological Perspective on Human Dignity, Equality and Freedom", 3.
} 
Para peserta didik diajak untuk senantiasa menyadari bahwa diri mereka adalah gambaran Allah. Dalam kisah penciptaan (Kej 1:27) Allah membentuk manusia sesuai dengan citra-Nya dan memberikan kepada manusia tempat khusus sebagai gambaran karya Allah di bumi. Imago Dei merujuk secara khusus pada dimensidimensi khusus dari sifat manusia yang membuat manusia mempunyai posisi di atas ciptaan lainnya, seperti kemampuan, kepribadian, kesadaran diri, kehendak bebas, dan kemampuan untuk menanggapi karya Tuhan. ${ }^{22}$ Hak untuk hidup, otonom/ kebebasan, dan dihargai/kesetaraan adalah tiga komponen paling mendasar dari konsep teologis tentang martabat manusia. Tanpa adanya kehidupan, tidak ada martabat.

Para peserta didik diajak untuk menyadari bahwa mereka mempunyai martabat yang sama dihadapan Allah, dan mereka diharapkan sampai pada penghargaan terhadap kehidupan manusia. Dalam Yoh 14:6, dikatakan bahwa Kristus adalah sumber kehidupan. Karya penyelamatan Allah melalui penebusan Kristus dalam sengsara, wafat, dan kebangkitan-Nya telah memulihkan hubungan manusia yang retak dengan Allah serta mengembalikan martabat manusia yang rusak karena perbuatan dosa. Melalui kebangkitan-Nya, Kristus mengalahkan maut dan penderitaan manusia. Karena itu, hidup yang sudah kita terima dalam Kristus harus dihargai.

Komponen penting lain dari martabat manusia adalah kebebasan. Dalam materi pembelajaran untuk kelas VI, pada bab pribadi dan lingkunganku (halaman 1-20) diajarkan tentang hak dan kewajiban manusia sebagai warga dunia. Salah satu hak dari manusia

22 N.Vorster, "A Theological Perspective on Human Dignity, Equality and Freedom", 3. adalah hak akan kebebasan. Kebebasan adalah anugerah yang diberikan Allah kepada manusia, terlepas dari dosanya. ${ }^{23}$ Sebagai citra Allah, manusia dianugerahi kehendak bebas, yang membuatnya bebas untuk memilih, bertindak, bekerja dan mengolah hidupnya. Karena itu, kebebasan yang ada di dalam diri manusia harus dilihat sebagai bagian yang tidak dapat diganggu gugat.

Tetapi perlu diingat bahwa kehendak bebas manusia ini bukanlah suatu legitimasi untuk bertindak secara anarki. Karena jika terjadi demikian, yang ada bukanlah suatu kehendak bebas tetapi sebuah perbudakan terhadap orang lain. Inilah yang terjadi ketika kebebasan digunakan untuk mendiskriminasi dan menyudutkan orang lain. Kebebasan adalah karakteristik yang tidak dapat diganggu gugat dan karenanya kebebasan dasar harus diterima dan tidak tunduk pada bentuk perendahan lainnya. Kebebasan yang dimiliki manusia selalu terkait dengan kewajiban manusia untuk menjaga keharmonisan hidup dalam dunia.

Martabat yang dimiliki manusia, membuat kedudukan semua manusia setara. Kesetaraan dalam martabat harus senantiasa diperjuangkan dan dipertahankan, supaya tidak terjadi bentuk penghinaan atau diskriminasi yang merupakan bentuk penghinaan dari kebebasan yang dimiliki manusia. Terkait dengan hal ini, para peserta didik didorong untuk saling melindungi, terutama melindungi hak-hak dasarnya. Perlindungan hak dasar ini menjadi perhatian pemimpin agama. Paus Fransiskus dan Malik Al-Tayeb menyatakan dalam "DokumenTentang Persaudaraan Manusia untuk Perdamaian Dunia dan Hidup Beragama" bahwa: 
Perlindungan hak-hak dasar anak untuk bertumbuh kembang dalam lingkungan keluarga, untuk memperoleh gizi baik, pendidikan dan dukungan, adalah tugas keluarga dan masyarakat. Tugas-tugas semacam itu harus dijamin dan dilindungi agar tidak diabaikan atau ditolak untuk anak mana pun di belahan dunia mana pun. Semua praktik yang melanggar martabat dan hak anak harus dikecam. ${ }^{24}$

Usaha yang ditanamkan dalam diri para peserta didik untuk menghormati martabat manusia terwujud dalam pendidikan bahwa keanekaragaman yang dimiliki oleh masyarakat sekitar adalah anugerah dari Allah. Semua kalangan memiliki keunikannya dan mempunyai hak-haknya untuk dilindungi. Maka diperlukan usaha untuk menghancurkan hambatan-hambatan sosial yang ada seperti perasaan yang menganggap diri sendiri atau kelompoknya lebih peting, lebih berharga dan patut dihormati daripada yang lain, sehinga menindas yang lain. Allah telah memampukan manusia untuk tidak meninggikan diri sendiri dengan jalan mengorbankan orang lain, tetapi untuk saling menghormati dan saling melayani dalam pelayanan yang rendah hati seperti yang telah dilakukan oleh Kristus untuk manusia (Flp 2: 5-7). ${ }^{25}$ Dalam suratsuratnya, Paulus pun menyatakan pentingnya kesetaraan dalam Kristus antara laki-laki dan perempuan (Gal 3:28) ${ }^{26}$ dan juga menerapkan prinsip kesetaraan di hadapan Allah antara orang tua dan anak, tuan dan budak (Ef 6:19). ${ }^{27}$ Semua manusia telah dijadikan sama dalam diri Kristus.

\footnotetext{
24 Departemen Dokpen KWI, "Dokumen Tentang Persaudaraan Manusia untuk Perdamaian Dunia dan Hidup Beragama: Perjalanan Apostolik Bapa Suci Paus Fransiskus ke Uni Emirat Arab (UEA) 3-5 Februari 2019", 23.

25 N.Vorster, "A Theological Perspective on Human Dignity, Equality and Freedom", 5.

26 Adela Yarbro Collins, "No Longer Male and Female (Gal 3:28)," Journal of Ethics in Antiquity and Christianity 1 (2019): 28.

27 Carrie A. Mile, "Patriarchy or Gender Equality? The Letter to the Ephesians on Submission, Headship, and Slavery," Dialogue: A Journal of Mormon Thought Vol. 39, No. 2 (2006): 70-95.
}

\section{Penghargaan martabat manusia} terungkap dan terwujud di dalam perlindungan terhadap keutuhan hidup serta tindakan masing-masing pribadi dan masyarakat yang menjunjung tinggi nilainilai kehidupan. ${ }^{28}$ Sikap adil menjadi hal penting bagi perkembangan setiap pribadi manusia untuk mendapatkan ruang lingkup yang terlindungi dan jelas, sebagaimana diajarkan dalam pelajaran untuk kelas VI pembahasan tentang masyarakat yakni terkait penegakan keadilan dan kejujuran (halaman 133-139). Allah menghendaki keadilan dan kejujuran, karena hal itu sungguh memberikan suasana kehidupan bersama yang nyaman dan harmonis.

Manusia mampu memahami nilai-nilai yang bisa diperjuangkan dalam hidupnya, seperti kehidupan, kebenaran, keindahan, keadilan, kedamaian, keharmonisan, dan kesejahteraan. Nilai-nilai ini harus diperjuangkan demi menghargai martabat manusia lainnya. Penghargaan terhadap pribadi-pribadi tercapai ketika manusia mampu untuk mengungkapkan secara bebas dan penuh dalam mencintai dirinya dan sesama. ${ }^{29}$ Maka dari itu, pengenalan akan diri sendiri menjadi sangat penting. Materi-materi pelajaran yang disampaikan dalam Buku Pendidikan Agama Katolik dan Budi Pekerti selalu dimulai dengan tema pembahasan "Pribadiku dan Lingkungan". Hal ini menandakan bahwa pengenalan peserta didik akan siapa dirinya akan menentukan pula sikapnya terhadap hidup iman dan relasinya dengan sesama. B. Lindars mengatakan bahwa manusia dapat mencapai keutuhannya ketika manusia mampu mencintai dirinya sendiri dan

\footnotetext{
28 CB. Mulyatno, Menguak Misteri Manusia: Pokok-Pokok Gagasan Filsafat Manusia (Yogyakarta: Kanisius dan Fakultas Teologi Universitas Sanata Dharma, 2009), 103.

29 CB. Mulyatno, Menguak Misteri Manusia: Pokok-Pokok Gagasan Filsafat Manusia, 104.
} 
sesamanya. $^{30}$ "Inilah perintah-Ku, yaitu supaya kamu saling mengasihi, seperti Aku telah mengasihi kamu" (Yoh 15:12).

Di dalam diri para peserta didik diharapkan selalu timbul kesadaran bahwa mereka mempunyai kesetaraan, yakni karena martabat mereka. Ajaran Gereja tidak membangun tembok pemisah antara berbagai dimensi kehidupan mereka, melainkan untuk membangun hubungan di antara mereka yang menunjukkan adanya sebuah kesatuan. ${ }^{31}$ Martabat yang ada di dalam diri mereka tidak hanya menjamin hak-haknya sebagai individu, tetapi juga hendaknya semakin membuat mereka untuk ikut serta dalam pelayanan dan kepedulian bagi sesama. Kesetaraan akan mengatasi ketidakadilan dan memaksa untuk memandang yang lain pada satu tingkat yang sama. Dengan demikian, hubungan antar para peserta didik harus terjalin dengan adanya interaksi. Hal inilah yang tercermin dalam dialog mereka sehari-hari.

Mencintai diri dan sesama secara sehat akan mendapatkan kemendalaman makna jika manusia sampai pada refleksi bahwa mencintai diri dan sesama adalah perwujudan cinta kepada Tuhan sendiri. ${ }^{32}$ Sebaliknya, egoisme diri justru akan menghancurkan kepribadian orang tersebut. Mencintai sesama manusia lewat nilai-nilai kehidupan akan membantu peserta didik untuk semakin menyadari dan mengenali jati dirinya sebagai mahluk spiritual yang terus berkembang ke arah kesempurnaan yakni persatuan dengan Tuhan sendiri. "Aku berkata kepadamu, sesungguhnya segala

\footnotetext{
30 B. Lindars, The Gospel of John: The New Century Bible Commentary (London: Morgan and Scott Publishing, 1987), 225-231.

31 N.Vorster, "A Theological Perspective on Human Dignity, Equality and Freedom", 5.

32 CB. Mulyatno, Menguak Misteri Manusia: Pokok-Pokok Gagasan Filsafat Manusia, 105.
}

sesuatu yang kamu lakukan untuk salah seorang dari saudara-Ku yang paling hina ini, kamu telah melakukannya untuk Aku" (Mat 25:4). Hal ini telah diteladankan oleh Tuhan Yesus sendiri dalam karya hidupNya, salah satunya dalam relasinya dengan wanita Samaria.

Dengan pendidikan Agama Katolik yang menerapkan nilai-nilai multikulturalisme, para peserta didik diajak untuk menjadi pribadi yang terbuka terhadap semua manusia. Karena para peserta didik inilah masa depan Gereja dan mereka inilah Gereja. Pendidikan yang demikian tentu membawa efek bagi kehidupan menggereja. Gereja bukanlah sebuah ghetto $^{33}$ yang memisahkan dirinya dari dunia nyata. Konsekuensinya, Gereja harus peka terhadap masalah-masalah yang terjadi di dunia ini, termasuk dengan persoalan konflik antar agama atau budaya. Tugas Gereja adalah mengembangkan rasa tanggung jawab untuk membawa pembaharuan dalam hidup manusia maupun masyarakat sosial yang merupakan tugas meneruskan karya keselamatan dari Kristus sendiri. ${ }^{34}$

Pendidikan Agama Katolik mengajarkan tentang doktrin-doktrin ajaran Gereja dan juga hal-hal etis terkait relasi dengan sesama di masyarakat. Para peserta didik dalam setiap pelajaran diajak untuk mampu mengintegrasikan atau merefleksikan hal-hal teologi yang diajarkan ke dalam kehidupan mereka sehari hari. Seperti yang terdapat pada materi "Yesus yang Memanggil Orang Berdosa” (halaman 64-68). Dalam materi itu dibahas juga sikap untuk tidak menjauhi mereka yang dianggap sampah masyarakat,

\footnotetext{
33 Dalam hal ini penulis mengartikannya sebagai sikap eksklusif terhadap dunia luar; menutup diri dengan daerah sekelilingnya.

34 Franz Magnis Suseno, Menjadi Saksi Kristus di tengah Masyarakat Majemuk (Jakarta:Obor,2004), 138.
} 
melainkan merangkul mereka sebagaimana Yesus juga merangkul orang berdosa. ${ }^{35}$

\section{Dialog untuk Merawat Multikulturalisme}

Setiap perjumpaan antar manusia melibatkan soal hati dan perasaan. Perjumpaan antar manusia berarti melihat yang lain sebagai diriku. Komunikasi dalam perjumpaan itu dapat terjadi bila masing-masing pihak diberi kesempatan dan keluasan untuk berpikir dan berbicara menurut pengalamannya masing-masing.

Sebuah perjumpaan sejati akan terjadi bila masing-masing pihak masuk ke dalam dirinya sendiri, mengoreksi dan mengkritik dirinya. Ia harus berani membuka pintu dirinya supaya orang lain mampu mengenal dirinya. Dalam proses berdialog, prinsip kebebasan sangatlah dipegang. Dalam "Dokumen Tentang Persaudaraan Manusia Untuk Perdamaian Dunia Dan Hidup Beragama” yang disetujui oleh Paus Fransiskus dan Imam Besar A-Azhar Ahmad Al-Tayyeb di Abu Dhabi, dituliskan:

Kebebasan adalah hak setiap orang: setiap individu menikmati kebebasan berkeyakinan, berpikir, berekspresi dan bertindak. Pluralisme dan keragaman agama, warna kulit, jenis kelamin, ras, dan bahasa dikehendaki Tuhan dalam kebijaksanaan-Nya, yang melaluinya Ia menciptakan umat manusia. Kebijaksanaan ilahi ini adalah sumber dari mana hak atas kebebasan berkeyakinan dan kebebasan untuk menjadi berbeda berasal. Oleh karena itu, fakta bahwa orang dipaksa untuk mengikuti agama atau budaya tertentu harus ditolak, demikian juga pemaksaan cara hidup budaya yang tidak diterima orang lain. ${ }^{36}$

35 FX. Dapiyanta dan Marianus Didi Kasmudi, Pendidikan Agama Katolik dan Budi Pekerti Kelas V, 66.

36 Departemen Dokpen KWI, "Dokumen Tentang Persaudaraan Manusia untuk Perdamaian Dunia dan Hidup Beragama: Perjalanan Apostolik Bapa Suci Paus Fransiskus ke Uni Emirat Arab (UEA) 3-5 Februari 2019", 18.
Kenyataannya, manusia memiliki pemahaman dan keyakinan yang berbeda mengenai suatu hal, tetapi hal ini tidak harus dipaksakan kepada yang lain. Perjumpaan kita dengan sesama tidak bermaksud untuk mempertobatkan yang lainnya. Pemaksaan terhadap yang lain merupakan tindakan nyata merebut kebebasan seseorang. Dialog antar agama yang dilakukan justru mengajak kita untuk semakin yakin dan komitmen dengan keyakinan kita masing-masing. Kita selalu dituntut untuk mempunyai sikap untuk saling membagi pemahaman dan pengalaman masing-masing sehingga masing-masing akan semakin memperkaya diri dan dapat hidup bersama.

\section{Sikap Belaskasih sebagai Sikap Dialog}

Dialog yang sudah menjadi sikap akan terwujud dalam tindakan yang berasal dari nilai-nilai universal seperti belaskasih, pengampunan, persaudaraan. Nilai belaskasih kepada sesama dapat mengurangi kecenderungan para peserta didik untuk menjadikan yang lain sebagai ancaman. Belaskasih dimanifestasikan dalam sikap kesabaran, pemberian tanpa pamrih dan juga pengampunan kepada orang-orang. ${ }^{37}$ Yohanes Paulus II mengatakan bahwa belaskasih adalah atribut dan kesempurnaan Allah yang paling besar, yang di dalamnya terdapat keadilan dan pengampunan. ${ }^{38} \mathrm{Hal}$ inilah yang dicontohkan secara sempurna oleh Yesus Kristus dalam pengorbanan-Nya di salib bagi manusia. Ia adalah Wahyu Allah yang secara radikal memberikan belaskasihNya.

Gereja dalam tugas perutusannya di dunia menjadi mediator dari belaskasih

\footnotetext{
37 Jadranka Garmaz \& Angelina Gašpar, "Education for Mercy: Comparative Analysis of The Pontifical Discourses," International Scientific Conference Proceedings 2 (2017): 58.

38 Jadranka Garmaz \& Angelina Gašpar, "Education for Mercy: Comparative Analysis of The Pontifical Discourses", 59-60.
} 
Allah itu sendiri. ${ }^{39}$ Maka sebagai bentuk perhatiannya kepada dunia pendidikan, Gereja mempunyai tanggungjawab untuk mendidik anak-anak dengan menanamkan nilai belaskasih Allah. Di tengah dunia yang menghadapi berbagai kekacauan karena kekerasan, kemiskinanan penindasan dan berbagai perilaku ketidak adilan terhadap sesama manusia, Gereja hadir sebagai perpanjangan tangan Allah untuk menyebarkan belaskasih Allah. Dunia yang seperti ini sangat membutuhkan belaskasih Allah. Gereja dipanggil untuk melakukan misinya yakni mewartakan pengalamannya akan Allah yang berbelaskasih. Belaskasih inilah yang mampu membuat manusia berpandangan secara tajam bahwa semua manusia adalah saudaranya.

Pendidikan dan penanaman nilai-nilai universal yang diberikan kepada para peserta didik juga hendaknya mengarah pada satu tujuan yakni terciptanya nilai persaudaraan. Persaudaraan yang terjalin antar para peserta didik akan menumbuhkan rasa solidaritas yang tinggi. Para peserta didik dilatih menjadi solider terhadap manusia lainnya terutama yang berkaitan dengan kesejahteraan hidup bersama baik secara sosial, spiritual maupun ekonomi. Maka ketika para peserta didik melihat atau dihadapkan pada situasi ketidakadilan, ancaman dan perendahan martabat manusia, para peserta didik dapat melawan hal ini dan menciptakan dunia yang lebih kondusif bagi terselenggaranya solidaritas. ${ }^{40}$

\section{KESIMPULAN}

Setelah melakukan pembahasan terkait nilai-nilai multikulturalisme dalam buku Pendidikan Agama Katolik dan Budi Pekerti untuk SD kelas V dan VI, dapat ditarik kesimpulan bahwa buku-buku tersebut mengandung nilai-nilai multikulturalisme. Nilai-nilai multikulturalisme yang ada semakin mudah dipahami karena pola penyajian materi dalam buku tersusun atas: relasi dengan diri, relasi dengan Tuhan, relasi dengan Gereja dan relasi dengan masyarakat. Hal tersebut oleh penulis dipandang sebagai sebuah pengajaran bahwa hidup beragama itu selalu terkait dengan kehidupan bersama dan bukan hanya menjalin relasi vertikal dengan Tuhan saja.

Nilai-nilai multikulturalisme dalam buku ini mengarahkan peserta didik untuk selalu memperhatikan dan menghargai perbedaan yang ada disekitar mereka. Rasa syukur atas perbedaan (suku, budaya, agama) hendaknya menjadi bagian utama dalam menjaga keharmonisan hidup bersama. Buku Pendidikan Agama Katolik dan Budi Pekerti ini telah mengarahkan para peserta didik untuk hidup beragama yang baik sekaligus memperhatikan sekitarnya, sesama manusia dan alam semesta.

Pendekatan pada penelitian ini masih sebatas penelitian terhadap materi-materi pelajaran Pendidikan Agama Katolik saja. Perlu diadakan penelitian lebih lanjut di

\footnotetext{
39 Jadranka Garmaz \& Angelina Gašpar, "Education for Mercy: Comparative Analysis of The Pontifical Discourses", 63.

40 Jadranka Garmaz \& Angelina Gašpar, "Education for Mercy: Comparative Analysis of The Pontifical Discourses", 68.
} 
sekolah-sekolah terkait dengan pelaksanaan Pendidikan Agama Katolik. Penelitian sebaiknya mencakup metode yang digunakan oleh para pengajar, jam pelajaran pendidikan agama yang tersedia, kualitas para pengajar baik secara akademis maupun moral, juga terkait dengan sarana dan prasarana di sekolah yang menunjang pendidikan multikulturalisme. Dengan demikian, akan diketahui seperti apa kualitas pendidikan agama yang diberikan untuk menunjang multikulturalisme di lingkungan sekolah.

Untuk semakin menanamkan nilainilai multikulturalisme diperlukan langkah selanjutnya yaitu bagaimana materimateri ini disampaikan dengan benar dan baik kepada para peserta didik supaya mereka dapat mengerti tentang nilainilai multikulturalisme dalam agama yang mereka yakini. Penyampaian materi kepada peserta didik hendaknya diimbangi dengan metode pengajaran yang tepat. Ada dua metode yang dapat diterapkan, yakni metode pendidikan langsung (direct) dan model pendidikan tidak langsung (indirect). Metode pendidikan langsung menekankan pada interaksi sosial secara langsung antar kelompok siswa (intergroup contact) yang beragam latar belakangnya. Model ini mengharuskan keragaman latar belakang siswa dalam proses pembelajaran. Metode pendidikan tidak langsung menekankan pada pengembangan kepribadian (personality development) para siswa yang terbuka terhadap perbedaan. ${ }^{41}$

Menurut penulis, metode pendidikan langsung dapat diterapkan dalam sistem belajar kelompok. Dengan belajar berkelompok, para peserta didik akan langsung mempraktikkan nilai-nilai multikulturalisme. Mereka bersosialisasi, belajar mendengarkan rekannya yang mungkin mempunyai pendapat yang berbeda, kemudian menarik jalan tengah untuk mencapai kesimpulan atau menjembatani perbedaan jawaban yang ada. Dengan demikian, para peserta didik diharapkan mampu untuk lebih menghargai orang lain, sekalipun ada perbedaan yang mencolok. Dalam proses ini, diharapkan terjadi suatu sikap saling membantu, di mana peserta didik yang cukup pandai membantu rekannya yang kurang mampu secara akademik, memberi semangat apabila terjadi kesalahan/kegagalan pada salah satu anggota dan mengapresiasi setiap usaha yang dilakukan oleh masing-masing anggota. Peran guru dalam tahap ini adalah melakukan pendampingan secara serius.

Kejelian dan kreativitas dari para pendidik (guru) hendaknya selalu diasah. Para pendidik hendaknya secara jeli melihat nilai-nilai multikulturalisme yang ada dalam materi pelajaran. Jika memang secara eksplisit tidak ada, maka diperlukan kejelian untuk membuat nilainilai multikulturalisme semakin kelihatan. Kejelian juga menyangkut tentang peluang yang ada dengan memanfaatkan waktuwaktu di dalam pelajaran maupun di luar pelajaran untuk menggerakkan peserta didik dalam rangka memperkuat sudut pandang multikulturalisme dalam diri masingmasing. 


\section{DAFTAR RUJUKAN}

Arifin, Syamsul. "Multikulturalisme dalam Skema Deradikalisasi Paham dan Gerakan Keagamaan Radikal di Indonesia”, dalam Proceeding AICIS XIV: Buku 2, ed. Muhammad Zain dkk. Samarinda: STAIN Samarinda, 2014. 162-194.

Collins, Adela Yarbro. "No Longer Male and Female (Gal 3:28)," Journal of Ethics in Antiquity and Christianity 1 (2019): 2739.

Dapiyanta, FX. dan Marianus Didi Kasmudi. Pendidikan Agama Katolik dan Budi Pekerti untuk SD Kelas V. Jakarta: Kementerian Pendidikan dan Kebudayaan, 2017.

Dapiyanta, FX. dan Marianus Didi Kasmudi. Pendidikan Agama Katolik dan Budi Pekerti untuk SD Kelas VI. Jakarta: Kementerian Pendidikan dan Kebudayaan, 2017.

Garmaz, Jadranka. dan Angelina Gašpar. "Education for Mercy - Comparative Analysis of The Pontifical Discourses," International Scientific Conference Proceedings 2 (2017): 56-72.

Hendroprioyono, A.M. Terorisme: Fundamentalis Kristen, Yahudi dan Islam. Jakarta: Buku Kompas, 2009.

Jackson, Robert. "Inclusive Study of Religions and World Views in Schools," Social Inclusion 4 (2016): 14-25.

Jose, Kuruvachira. "Interreligious Dialogue in Dialogue and Mission," tersedia dari https://www.euclid.int/papers/JOSE\%20 KURU\%20---\%20INTERRELIGIOUS\%20 DIALOGUE\%20IN\%20DIALOGUE\%20 AND\%20MISSION.pdf; diakses pada 21 Juli 2020 .

Parekh. Rethinking Multikulturalism: Keberagaman Budaya dan Teori Politik, diterjemahkan dari Rethinking Multiculturalism, Cultural Diversity and Political Theory, oleh Bambang Kukuh Adi. Yogyakarta: Kanisius, 2008.

Lindars, B. The Gospel of John: The New Century Bible Commentary. London: Morgan and Scott Publishing, 1987.

Mahfud, Choirul. Pendidikan Multikultural. Yogyakarta: Pustaka Pelajar, 2006.
Mile, Carrie A. "Patriarchy or Gender Equality? The Letter to the Ephesians on Submission, Headship, and Slavery," Dialogue: A Journal of Mormon Thought Vol. 39, No. 2 (2006): 70-95.

Mulyadi, Mohammad. "Penelitian Kuantitatif dan Kualitatif serta Pemikiran Dasar Menggabungkannya," Jurnal Studi Komunikasi dan Media 15 (2011): 127138.

Mulyatno, CB. Menguak Misteri Manusia: Pokok-Pokok Gagasan Filsafat Manusia. Yogyakarta: Kanisius dan Fakultas Teologi Universitas Sanata Dharma, 2009.

Muslim. "Nilai-Nilai Pendidikan Multikultural dalam Buku Teks Bahasa Indonesia untuk Peserta Didik SMP," Riksa Bahasa 2 (2016): 55-66.

Nuswantari, Nusi. "Model Pembelajaran NilaiNilai Toleransi untuk Anak Sekolah Dasar," Premiere Educandum: Jurnal Pendidikan Dasar dan Pembelajaran 8 (2018): 41-53.

Suseno, Franz Magnis. Menjadi Saksi Kristus di tengah Masyarakat Majemuk. Obor: Jakarta, 2004.

Syam, Nur. Tantangan Multikulturalisme Indonesia: Dari Radikalisme Menuju Kebangsaan. Yogyakarta: Kanisius, 2009.

Tilaar, H.A.R. Multikulturalisme: Tantangantantangan Global Masa Depan dalam Transformasi Pendidikan Nasional. Jakarta: Grasindo, 2004.

van Bowen, Theodora. Religious Education for Tolerance: An Exploratory Study of the Policies and Practises of Religious Education in Public, Christian and Islamic Secondary Schools in the Netherlands and Indonesia. Nijmegen: Radboud Universiteit Nijmegen, 2017.

Vorster, N. "A Theological Perspective on Human Dignity, Equality and Freedom," Verbum et Ecclesia 33 (2012): 1-6.

Yaqin, Ainul. Pendididkan Multikultural: CrossCultural Understanding untuk Demokrasi dan Keadilan. Yogyakarta: Nuansa Aksara, 2005. 
